\title{
Risk analysis of heavy metal contaminated habitats using a wolf spider, Pardosa astrigera (Araneae: Lycosidae)
}

\author{
M.-P. Jung, H. Kim, S.-T. Kim \& J.-H. Lee \\ Department of Agricultural Biotechnology, \\ Seoul National University, Korea
}

\begin{abstract}
Using biological indicators to evaluate the healthiness of ecological habitats is increasingly important. Spiders are considered very useful candidates for this purpose, but few studies have been conducted. This study was conducted to investigate a relationship between heavy metal (cadmium $(\mathrm{Cd})$ and lead $(\mathrm{Pb})$ ) contamination levels in soil habitats and their accumulations in a wolf spider, Pardosa astrigera, and to develop a bio-evaluation system for soil risk assessment of $\mathrm{Cd}$ and $\mathrm{Pb}$ using $P$. astrigera. Contents of $\mathrm{Cd}$ and $\mathrm{Pb}$ in a female adult $P$. astrigera and soil were estimated in nine sites in September, 2004 in Korea. $\mathrm{Cd}$ and $\mathrm{Pb}$ contamination levels in soil were well described by the $\mathrm{Cd}$ and $\mathrm{Pb}$ content of female adult $P$. astrigera by power functions. A bio-evaluation system is proposed for a soil risk assessment of $\mathrm{Cd}$ and $\mathrm{Pb}$ with $P$. astrigera using the amount of bioaccumulation and the lethal body concentration.

Keywords: Pardosa astrigera, heavy metal, $\mathrm{Cd}, \mathrm{Pb}$, biological indicator, bioaccumulation.
\end{abstract}

\section{Introduction}

The practical soil quality evaluation methodology has not been improved much because the progress in soil ecology theory has not led to practical strategies for soil evaluation [1]. One way of improving soil quality evaluation methods is to develop ecological indicator systems that can be used in soil quality assessments. Ecological indicators are useful instruments to bridge the gap between soil science and soil regulation practice [2]. 
Heavy metals (e.g. $\mathrm{Cd}$ and $\mathrm{Pb})$ are commonly investigated components of soil pollution because of their toxicity and stability. Field and laboratory studies were carried out to investigate bioaccumulation and effect of heavy metals on soil invertebrates [3-10]. However, few attempts have been made to predict heavy metal contamination levels in soil by estimating bioaccumulation of heavy metals in soil invertebrates. Although direct measurement of soil for heavy metal contamination is useful, it may be costly and often incorrect because of high variation in soil contaminations within the site. In this regard, using biological indicators for evaluation of healthiness of ecological habitats for heavy metal contamination is perhaps more reliable because actively moving carnivorous arthropods can cover a relatively wide range and accumulate heavy metals by bio-concentration through a food chain as well as by direct soil contact in the habitats. Spiders are considered very useful candidates for this purpose. Grounddwelling hunting spiders may reflect the pollution level of their habitats better than web-building spiders [11]. Pardosa astrigera can be a good candidate because it is a ground-dwelling hunting spider, can be easily sampled, is one of the dominant species in terrestrial ecosystems and its major diets are springtails and dipterans which inhabit soil [12-14].

Objectives of this study, therefore, are to quantify relationships between $\mathrm{Pb}$ and Cd levels in soil and their accumulations in a wolf spider, $P$. astrigera and to develop a bio-evaluation system for soil risk assessment of $\mathrm{Pb}$ and $\mathrm{Cd}$ using P. astrigera.

\section{Materials and methods}

\subsection{Study sites and sampling methods}

Five agricultural (A, B, F, H, and I), two residential (C and $\mathrm{G}$ ), and two industrial sites ( $\mathrm{D}$ and $\mathrm{E}$ ) were selected according to expected differences in $\mathrm{Cd}$ and $\mathrm{Pb}$ contamination levels in soil (Figure 1). Five sites (A, B, C, D, and E) were selected along the Singil stream between Ansan and Sihueng city in Korea. Residential and industrial sites were located along the Singil stream.

Hand-collecting was used to collect female adult $P$. astrigera in each site to estimate bioaccumulation in September, 2004. Thirty individuals were collected at the same time from each site. Three topsoil samples (ca. 500g each) were taken at the area where spiders were collected.

\subsection{Exposure of heavy metals and determination of heavy metal contents in $P$. astrigera and soil}

$\mathrm{Cd}$ and $\mathrm{Pb}$ levels in field sampled soil and female adult $P$. astrigera were measured. For the measurement of heavy metal content in the spiders, five $P$. astrigera were grouped as one and measured. Thus, six measurements were made for each site. For measurement of soil, three measurements were made for each site. Also, dry weights of examined P. astrigera were measured. 


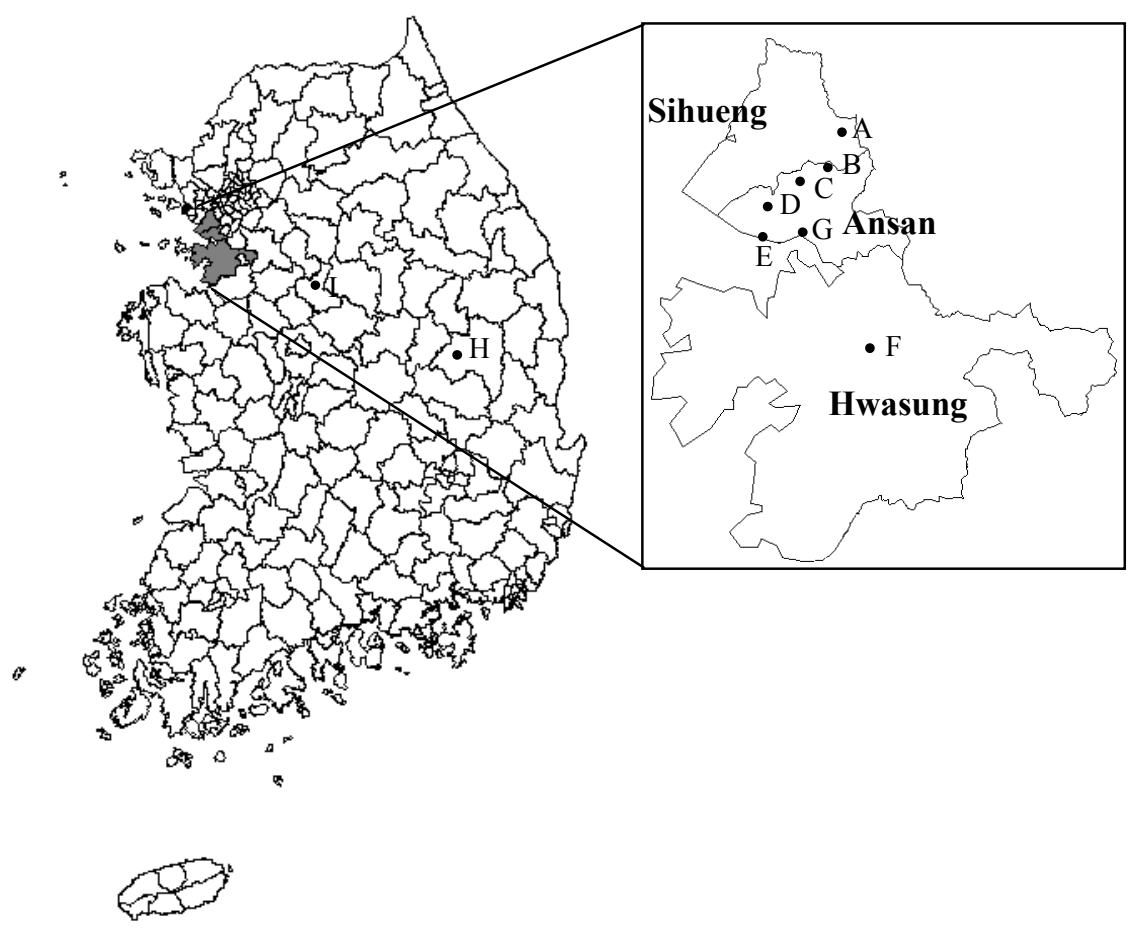

Figure 1: $\quad$ Map of study sites.

Female, sub adult or adult $P$. astrigera were collected from the unpolluted site and were exposed to $\mathrm{Cd}$ and $\mathrm{Pb}$ by dietary uptake in the laboratory. Adult Drosophila melanogaster reared by exposing $\mathrm{Cd} 10 \mathrm{mg} / \mathrm{kg}$ and $\mathrm{Pb} 100 \mathrm{mg} / \mathrm{kg}$, respectively, were used as foods. Three fruit flies per day were provided to individual $P$. astrigera until $P$. astrigera died. Then, $\mathrm{Cd}$ and $\mathrm{Pb}$ levels of five $P$. astrigera were analyzed to estimate lethal body concentration. Ten replications were conducted in this experiment. Also, dry weight of examined P. astrigera was measured.

For the measurement of $\mathrm{Cd}$ and $\mathrm{Pb}$, ICP (Inductively Coupled Plasma Emission Spectrometer) was used at the NICEM (National Instrumentation Center for Environmental Management) in Seoul National University.

\subsection{Statistical analysis}

Power functions were used to describe the relationship between bioaccumulation of $P$. astrigera and heavy metal contents in soil. The equations are:

$$
\begin{gathered}
\mathrm{y}_{1}=\mathrm{a}_{1}+\mathrm{b}_{1} \mathrm{x}_{1}{ }^{\mathrm{c} 1} \\
\mathrm{y}_{2}=\mathrm{a}_{2} \mathrm{x}_{2}{ }^{\mathrm{b} 2}
\end{gathered}
$$


where, $\mathrm{y}_{1}$ and $\mathrm{y}_{2}$ are $\mathrm{Cd}$ and $\mathrm{Pb}$ concentration in soil, respectively. $\mathrm{x}_{1}$ and $\mathrm{x}_{2}$ are $\mathrm{Cd}$ and $\mathrm{Pb}$ concentration in female adult $P$. astrigera, respectively.

\section{Result and discussion}

\subsection{Relationship of bioaccumulation of $P$. astrigera and concentration in soil of Cadmium and Lead}

The lethal concentrations of $\mathrm{Cd}$ and $\mathrm{Pb}$ for $P$. astrigera in this experiment were measured. The $\mathrm{Cd}$ and $\mathrm{Pb}$ concentration in the female adult $P$. astrigera and soil varied among sites: very high in site $\mathrm{C}, \mathrm{E}$, and $\mathrm{G}$ (residential or industrial sites), low in site A and I (agricultural sites) (Table 1). The $\mathrm{Cd}$ concentration in $P$. astrigera was higher by 10-700 times than that in soil. The $\mathrm{Pb}$ concentration in $P$. astrigera was higher by 1-20 times than that in soil. It was reported that spiders accumulated $\mathrm{Cd}, \mathrm{Cu}$, and $\mathrm{Zn}$ to the concentrations greater than those present in the soil but did not accumulate $\mathrm{Pb}$ [11]. Like Steatoda bipunctata (Theridiidae) [14], P. astrigera may behave as a regulator for $\mathrm{Pb}$, which accumulates heavy metals to a certain level and then excretes them beyond the level, but as an accumulator for $\mathrm{Cd}$.

Table 1: Mean concentration of cadmium and lead in female adult P. astirgera and soil.

\begin{tabular}{|c|c|c|c|c|}
\hline \multirow{2}{*}{ Sites } & \multicolumn{2}{|c|}{$\mathrm{Cd}(\mu \mathrm{g} / \mathrm{g})$} & \multicolumn{2}{c|}{$\mathrm{Pb}(\mu \mathrm{g} / \mathrm{g})$} \\
\cline { 2 - 5 } & Female adult & Soil & Female adult & Soil \\
\hline $\mathrm{A}$ & 7.14 & 0.03 & 37.97 & 1.60 \\
\hline $\mathrm{B}$ & 11.33 & 0.25 & 51.35 & 8.50 \\
\hline $\mathrm{C}$ & 17.04 & 1.46 & 79.31 & 52.20 \\
\hline $\mathrm{D}$ & 22.79 & 0.27 & 61.35 & 17.20 \\
\hline $\mathrm{E}$ & 36.60 & 1.41 & 101.78 & 96.70 \\
\hline $\mathrm{F}$ & 16.17 & 0.10 & 66.55 & 2.80 \\
\hline $\mathrm{G}$ & 30.14 & 0.95 & 105.96 & 69.50 \\
\hline $\mathrm{H}$ & 8.00 & 0.28 & 69.93 & 30.20 \\
\hline $\mathrm{I}$ & 7.20 & 0.01 & 53.88 & 2.70 \\
\hline
\end{tabular}

The relationship between bioaccumulation of female adult $P$. astrigera and heavy metal concentration in soil was well described by power functions (Figure 2). However, these models must be applied to the conditions of $<2 \mathrm{mg} / \mathrm{kg}$ for $\mathrm{Cd}$ and $<120 \mathrm{mg} / \mathrm{kg}$ for $\mathrm{Pb}$ in soil, respectively because two models were developed using $P$. astrigera collected in mostly moderately contaminated habitats. Further calibration studies may be needed in habitats of a higher contamination level. 

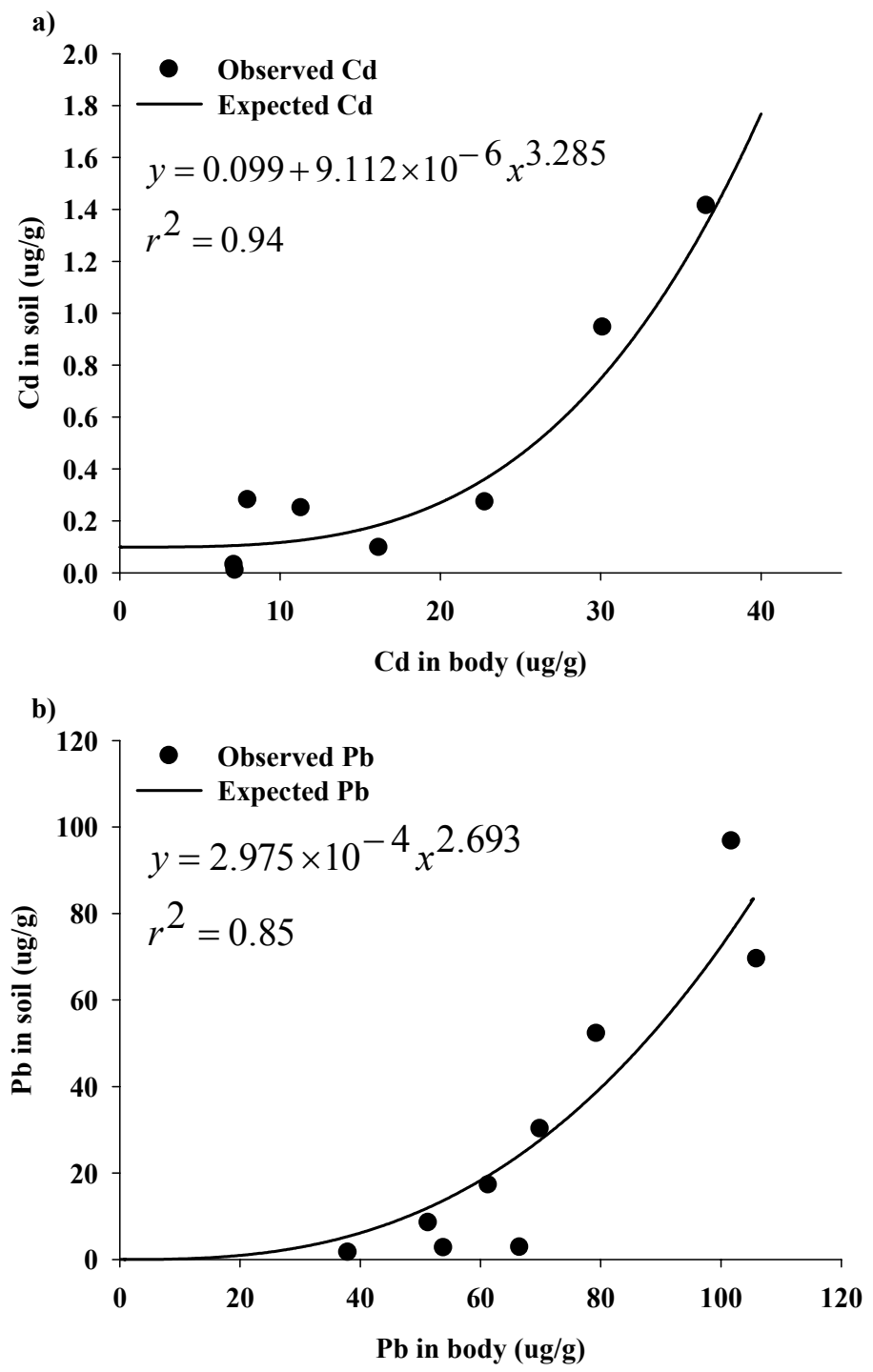

Figure 2: Relationships between heavy metal content in adult female of P. astrigera and soil. a: $\mathrm{Cd}, \mathrm{b}: \mathrm{Pb}$.

\subsection{Use of $P$. astrigera in risk assessment of heavy metal contamination in soil}

The bio-indicator index for toxicant residues, $\beta$, as the average of the quotient of the observed residue in a species and the internal threshold concentration, and 
the reference system for evaluating bio-indicator index for toxicant residues (Figure 3a) were proposed by van Straalen [10]. The bio-indicator index for toxicant residues can be interpreted as the fraction of the internal threshold concentration that is occupied by the residue: e.g. $<0.01$ as negligible risk in the reference system. In our study (i.e. the modified reference system), the threshold of negligible risk was modified as $<0.02$ because the amount of bioaccumulation of $P$. astrigera was very diverse from $0 \mathrm{mg} / \mathrm{kg}$ to $20 \mathrm{mg} / \mathrm{kg}$ for $\mathrm{Cd}$, and from $0 \mathrm{mg} / \mathrm{kg}$ to $60 \mathrm{mg} / \mathrm{kg}$ for $\mathrm{Pb}$ in uncontaminated sites. In Korea, action level for $\mathrm{Cd}$ and $\mathrm{Pb}$ contamination in soil is $4 \mathrm{mg} / \mathrm{kg}$ and $300 \mathrm{mg} / \mathrm{kg}$ in agricultural areas, respectively. The modified reference system is shown in Figure $3 \mathrm{~b}$.
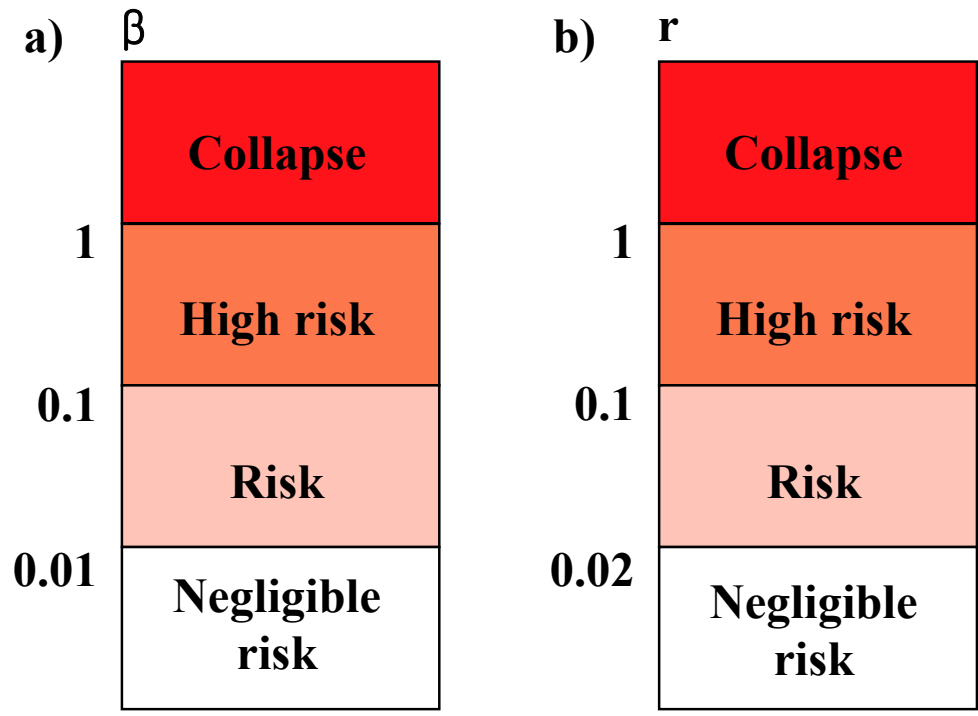

Figure 3: a) The reference system for evaluation the bioindicator index for toxicant residues, $\beta$ proposed by Van Straalen [10]. b) The modified reference system for evaluation the heavy metal contamination in soil. $\mathrm{r}$ is risk ratio (the quotient of the observed residue in a species and the internal threshold concentration).

In the laboratory experiment, estimated lethal body concentration (mean \pm s.e) of $P$. astrigera for $\mathrm{Cd}$ and $\mathrm{Pb}$ was $1,050.5 \pm 18.61 \mathrm{mg} / \mathrm{kg}$ and $3,122.8 \pm 35.04 \mathrm{mg} / \mathrm{kg}$, respectively. Using these values, the risk ratios (the quotient of the observed residue in a species and the internal threshold concentration) for study sites for $\mathrm{Cd}$ and $\mathrm{Pb}$ were calculated (Table 2). According to the modified reference system, for $\mathrm{Cd}$, the site $\mathrm{A}, \mathrm{B}, \mathrm{C}, \mathrm{F}, \mathrm{H}$, and I were characterized as a negligible risk zone, while the site $\mathrm{D}, \mathrm{E}$, and $\mathrm{G}$ were evaluated as a risk zone. For $\mathrm{Pb}$, the site $\mathrm{A}, \mathrm{B}$, and $\mathrm{I}$ were evaluated as a negligible risk zone while other sites were as a risk zone. This system is highly 
compatible with direct measurement of soil and is applicable for evaluation of soil habitat contamination.

Further calibration and validation studies are necessary since there are some limitations in using lethal body concentration [10]: e.g. physiological conditions and presence of other metals in the body can affect the lethal dosage.

Table 2: Risk assessment of this nine study sites using risk ratio (r) estimated from $\mathrm{Cd}$ and $\mathrm{Pb}$ concentration in $P$. astrigera.

\begin{tabular}{|c|c|c|c|c|}
\hline \multirow{2}{*}{ Sites } & \multicolumn{2}{|c|}{ Cd } & \multicolumn{2}{c|}{$\mathrm{Pb}$} \\
\cline { 2 - 5 } & Observed residue & $\mathrm{r}$ & Observed residue & $\mathrm{r}$ \\
\hline $\mathrm{A}$ & 7.14 & 0.007 & 37.97 & 0.012 \\
\hline $\mathrm{B}$ & 11.33 & 0.011 & 51.35 & 0.016 \\
\hline $\mathrm{C}$ & 17.04 & 0.016 & 79.31 & 0.025 \\
\hline $\mathrm{D}$ & 22.79 & 0.022 & 61.35 & 0.020 \\
\hline $\mathrm{E}$ & 36.60 & 0.035 & 101.78 & 0.033 \\
\hline $\mathrm{F}$ & 16.17 & 0.015 & 66.55 & 0.021 \\
\hline $\mathrm{G}$ & 30.14 & 0.029 & 105.96 & 0.034 \\
\hline $\mathrm{H}$ & 8.00 & 0.008 & 69.93 & 0.022 \\
\hline $\mathrm{I}$ & 7.20 & 0.007 & 53.88 & 0.017 \\
\hline
\end{tabular}

\section{Acknowledgement}

This work was supported by Ministry of Environment, Republic of Korea (200409001-0012-0) and the Brain Korea 21 program.

\section{References}

[1] Van Straalen, N.M., Assessment of soil contamination - a functional perspective. Biodegradation, 13, pp. 41-52, 2002.

[2] Van Straalen, N.M., The use of soil invertebrates in ecological surveys of contaminated soils (Chapter 6). Vital Soil, ed. P. Doelman \& H. Eijsackers, Elsevier: Amsterdam, pp. 159-195, 2004.

[3] Belotti, E., Assessment of a soil quality criterion by means of a field survey. Applied Soil Ecology, 10, pp. 51-63, 1998.

[4] Dallinger, R. \& Rainbow, P.S., (eds). Ecotoxicology of Metals in Invertebrates, Lewis Publishers: Boca Raton, 1993.

[5] Heikens, A., Peijnenburg, W.J.G.M., \& Hendriks, A.J., Bioaccumulation of heavy metals in terrestrial invertebrates. Environmental Pollution, 113, pp. 385-393, 2001.

[6] Hussein, M.A., Obuid-Allah, A.H., Mohammad, A.H., Scott-Fordsmand, J.J., \& Abd El-Wakeil, K.F., Seasonal variation in heavy metal accumulation in subtropical population of the terrestrial isopod, Porcellio Laevis. Ecotoxicology and Environmental Safety, 63, pp. 168-174, 2006 
[7] Laing, G.D, Bogaert, N., Tack, F.M.G., Verloo, M.G., \& Hendrickx, F., Heavy metal contents $(\mathrm{Cd}, \mathrm{Cu}, \mathrm{Zn})$ in spiders (Pirata piraticus) living in intertidal sediments of the river Scheldt estuary (Belgium) as affected by substrate characteristics. The Science of the Total Environment, 289, pp. 71-81, 2002.

[8] Ross, S.M., Toxic Metals in Soil/Plant Systems, John Wiley and Sons: Chichester, 1994.

[9] Skubala, P \& Kafel, A., Oribatid mite communities and metal bioaccumulation in orbatid species (Acari, Oribatida) along the heavy metal gradient in forest ecosystems. Environmental Pollution, 132, pp. 51-60, 2004.

[10] van Straalen, N.M. \& Krivolutsky, D.A., (eds). Bioindicator Systems for Soil Pollution, Kluwer Academic Publishers: Dordrecht, 1996.

[11] Marc, P., Canard, A., \& Ysnel, F., Spiders (Araneae) useful for pest limitation and bioindication, Agriculture, Ecosystems and Environment, 74, pp. 229-273, 1999.

[12] Im, M.S. \& Kim, S.T., Field Guide of Korean Spiders, Konkuk University Press, Seoul, p 170, 2000 (in Korean).

[13] Miyashita, K., Seasonal Change of population Density and Some Characteristics of overwintering Nymph of Lycosa T-insignita Boes. Et STR. (Araneae: Lycosidae). Applied Entomology and Zoology, 4, pp. 1-8, 1969.

[14] Nyffeler, M \& Benz, G., Feeding ecology and predatory importance of wolf spiders (Pardosa spp.) (Araneae, Lycosidae) in winter wheat fields. Journal of Applied Entomology, 106, pp. 123-134, 1988.

[15] Clausen, I.H.S., On the dynamics of cadmium and lead in Steatoda bipunctata (Araneae). Proc. Of the $5^{\text {th }}$ Int. Conf. Bioindicatores Deteriorisations Regionis, eds. J. Bohac \& Ruzicka, pp. 315-318, 1989. 